\title{
Perubahan Sosial Ekonomi Masyarakat Nelayan Pasca Transmigrasi Daerah di Kampung Teluk Ambun Kabupaten Aceh Singkil
}

\author{
Wardah Muharriyati Siregar ${ }^{1}$, Rani Putri $^{2}$, Mursyidin $^{3}$ \\ ${ }^{1}$ Universitas Teuku Umar \\ ${ }^{2,3}$ Universitas Malikussaleh \\ wardah_muharriyanti@yahoo.com¹, raniputri1199@gmail.com², mursyidinza@unimal.ac.id ${ }^{3}$
}

\begin{abstract}
On December 26, 2004 and March 28, 2005, Aceh experienced an earthquake phenomenon. These two earthquake phenomena caused damage to the Aceh region, including the Aceh Singkil area in Kampung Teluk Ambun. As a result, Teluk Ambun Village, which is in daerah aliran sungai (DAS), had to be moved. Currently Teluk Ambun Village is located in transmigrasi daerah aliran sungai (Trandas) which is in the plantation area. As for the problem in this research is how the socio-economic changes in fishing communities after the occurrence of regional transmigration. The method used is a qualitative research method with a descriptive type. To obtain the data used the method of observation, interviews, and documentation. The results of this study indicate that there are socio-economic changes in fishing communities after regional transmigration, namely changes in fishermen's income, then some fishermen make a shift in their main livelihood, namely as oil palm farmers. In addition, there is a change in the mindset of the fishing community about the importance of education and knowledge, fishermen are paying attention to the education of their children so they can get a good job.
\end{abstract}

\section{Keywords: Fishing community, socio-economic, Singkil, Teluk Ambun}

\section{PENDAHULUAN}

Pada tanggal 26 Desember 2004 Aceh mengalami fenomena gempa bumi yang mengakibatkan terjadinya bencana tsunami. Kemudian pada tanggal 28 Maret 2005, Aceh kembali dikejutkan fenomena gempa bumi yang berpusat di pulau Nias. Kedua fenomena gempa bumi ini sama-sama memakan korban jiwa dan menimbulkan kerusakan infrastruktur. Salah satu kampung yang berada di Kabupaten Aceh Singkil, yaitu Kampung Teluk Ambun mengalami kerusakan akibat kedua fenomena gempa bumi di atas. Tidak ada korban jiwa, namun kerusakan yang ada membawa dampak yang sangat besar kampong tersebut.

Kampung Teluk Ambun yang berada di sepanjang aliran sungai (DAS), mengalami penurunan dataran pasca gempa pada tanggal 26 Desember 2004. Kondisi 
masyarakat yang belum usai akibat gempa tersebut, penurunan permukaan tanah kembali dialami oleh masyarakat Teluk Ambun yang diakibatkan oleh gempa bumi yang terjadi pada tanggal 28 Maret 2005. Penurunan permukaan tanah yang terjadi mencapai 1 meter, hingga menyebabkan permukaan air sungai lebih tinggi dari permukaan tanah di Kampung Teluk Ambun. Akibatnya Kampung Teluk Ambun harus dipindahkan ke area yang lebih aman dan layak.

Kampung Teluk Ambun selesai dipindahkan pada tahun 2007 oleh suatu organisasi dengan persetujuan pemerintah setempat ke kawasan yang berada di area perkebunan, kawasan ini pun berjarak dekat dengan ibu kota Aceh Singkil. Kawasan ini disebut dengan Daerah Trandas (transmigrasi daerah aliran sungai) yang jauh dengan aliran sungai. Masyarakat Teluk Ambun yang sebelumnya bertempat tinggal di daerah aliran sungai, memiliki mata pencaharian utama sebagai nelayan dalam memenuhi kebutuhan hidup, dengan menggantungkan hidup dari hasil sungai yaitu menangkap ikan dan kerang (lokan). kini mata pencaharian utama tersebut akan sulit ditekuni masyarakat setelah bertempat tinggal dikawasan baru, yaitu daerah Trandas yang merupakan area perkebunan.

Terjadinya transmigrasi Kampung Teluk Ambun dari area aliran sungai ke area perkebunan, menghantarkan masyarakat pada banyak perubahan sosial terutama perubahan pada aspek mata pencaharian. Masyarakat nelayan dituntut untuk menyesuaikan diri dengan memanfaatkan sumber daya alam yang ada di wilayah tersebut untuk bertahan dan melangsungkan hidup. Kawasan Teluk Ambun saat ini jauh dengan sumber daya alam (sungai) yang telah memberikan dampak yang baik pada mata pencaharian para nelayan, dimana sebelumnya nelayan tersebut secara turun temurun adalah sebagai nelayan tradisional yang melangsungkan hidupnya pada sumberdaya alam yaitu sungai. Pekerjaan yang lain hanya menjadi pekerjaan tambahan sebagai bentuk antisipasi jika pendapatan sebagai nelayan tradisional tidak mencukupi, sehingga kelangsungan hidupnya dapat dipertahankan. Namun, sejak terjadinya transmigrasi, mata pencaharian mereka sebagai nelayan mengalami persoalan.

Ketergangguan yang dirasakan terlihat dari ketidak mampuan mereka (para nelayan) melakukan aktivias seperti biasanya dalam memenuhi kebutuhan hidup karena jarak antara pemukiman dengan sungai sangat jauh. Namun tidak semua nelayan merasakan dampak yang sama pasca terjadinya transmigrasi daerah. Ada nelayan yang mengakui dan memiliki pola pikir bahwa potensi kekayaan sumber daya alam di setiap wilayah berbeda-beda. Pemikiran seperti ini, cenderung membawa nelayan bersikap menerima bahkan menyesuaikan, sehingga nelayan dengan pemikiran ini dapat memanfaatkan sumber daya alam yang ada. Dengan terjadinya transmigrasi daerah, mereka berkesempatan mencari pekerjaan diluar sebagai nelayan yang merupakan pekerjaan yang diwariskan/turun temurun.

Sehubungan dengan itu, kawasan Kampung Teluk Ambun yang merupakan perpindahan antara kawasan perairan (sungai) dan kawasan daratan (perkebunan) 
merupakan daerah yang berada diantara dua sumber daya alam, kedua daerah ini memiliki keunggulan/kekayaan yang berbeda. Dimana kawasan perairan (sungai) memiliki keunggulan yang di dalamnya berkaitan dengan kekayaan seperti ikan, kerang dan segala jenis hasil perairan. Berbeda dengan kawasan daratan (perkebunan) yang memiliki keunggulan yang berkaitan dengan bercocok-tanam, ternak, dan jenis hasil tanah lainnya. Kedua sumber daya ini memiliki cara yang berbeda dalam pemanfaatannya, keduanya membutuhkan keterampilan berbeda dalam mengeksplor sumber daya agar bisa mendapatkan hasil yang baik.

Masyarakat nelayan Teluk Ambun yang memiliki keterampilan dan pengetahuan terbatas, harus mampu membuka cakrawala pemikiran di luar pekerjaan sebagai nelayan. Masyarakat yang memiliki pengetahuan dan keterampilan yang baik akan dapat menyesuaikan diri terlihat dari pekerjaan yang ditekuni berubah. Masyarakat yang terampil dan kaya dengan pengetahuan, mampu melakukan perubahan pada mata pencaharian. Namun beberapa nelayan yang memiliki pengetahuan dan keterampilan yang terbatas, tetap bertahan pada pekerjaanya sebagai nelayan, sekalipun alat (sungai) memiliki jarak yang jauh dari rumah. Berdasarkan uraian di atas, penulis tertarik untuk melakukan penelitian dengan judul perubahan sosial ekonomi masyarakat nelayan pasca transmigrasi daerah di Kampung Teluk Ambun Kecamatan Singkil Utara Kabupaten Aceh Singkil.

\section{TINJAUAN PUSTAKA}

\section{Masyarakat Nelayan}

Koendjaraningrat (1996:119) Masyarakat atau society diterjemahkan sebagai kumpulan manusia yang saling berinteraksi antara satu dengan yang lainnya. Selain itu, kita juga dapat melihat dari karya Koendjaraningrat yang membuat suatu matriks tentang masyarakat yang dapat dipahami sebagai suatu komunitas.

Horton et al (1991) dalam Satria (2015) menjelaskan bahwa masyarakat merupakan kumpulan manusia yang relatif mandiri, hidup dan mendiami wilayah tertentu, berdampingan dengan manusia lainnya dalam waktu yang lama. Kumpulan manusia ini juga memiliki budaya yang khas dalam melakukan aktivitas-aktivitasnya. Selain itu sekelompok manusia itu juga memiliki norma-norma serta kepercayaan yang dianut secara bersama-sama

Sastrawidjaya (2002) menjelaskan masyarakat nelayan merupakan sekumpulan manusia yang hidup dengan menggantungkan mata pencahariannya pada hasil laut atau pesisir. Sedangkan Imron (2003) menjelaskan bahwa masyarakat nelayan sebagai sekelompok masyarakat yang menggantungkan hidupnya pada hasil laut, baik dengan melakukan penangkapan dilaut maupun dengan hasil budidaya. Masyarakat nelayan ini pada umumnya menetap atau mendiami pinggir pantai atau wilayah pesisir dengan harapan tempat mereka tinggal berdekatan dengan tempat mereka mencari sumberdaya atau mata pencahariannya. 
Nelayan merupakan istilah yang digunakan untuk menjelaskan suatu komunitas masyarakat tertentu yang mendiami atau bertempat tinggal di wilayah pesisir, komunitas ini memiliki khas yang menggantungkan mata pencahariannya pada hasil laut. Masyarakat nelayan ini menjadikan sumber daya laut sebagai objek mata pencahariannya dengan berprofesi sebagai penangkap hasil laut atau budi daya. Kelompok masyarakat nelayan sangat bergantung pada hasil-hasil laut, sehingga pendapatan mereka akan berdampak ketika terjadinya pergantian musim.

Masyarakat nelayan juga sering diistilahkan dengan masyarakat pesisir. Kusnadi (2006) menjelaskan bahwa masyarakat pesisir memiliki perbedaan karakteristik dengan masyarakat agraris. Istilah masyarakat agraris dimaknai sebagai kelompok masyarakat yang terkontrol dalam mengelola sumber daya alam. Sedangkan masyarakat pesisir atau nelayan bersifat terbuka dalam pengelolaan sumber daya alamnya. Dampaknya masyarakat nelayan atau pesisir harus berpindah-pindah tempat untuk mendapatkan hasil yang optimal dalam melakukan pekerjaan atau mata pencahariannya.

Merujuk pada Kusnadi (2006:2) masyarakat nelayan atau masyarakat pesisir dapat dikelompokkan pada tiga kelompok yaitu:

1) Pemilik alat-alat produksi

Nelayan dibagi menjadi menjadi dua kelompok. Pertama, nelayan pemilik, yaitu nelayan yang memiliki atau menguasai alat produksi untuk melakukan berbagai proses kegiatan yang berhubungan dengan kegiatan nelayan atau pesisir. Kedua, nelayan buruh, kelompok nelayan ini memiliki keterbatasan dalam menguasai alatalat produksinya, nelayan buruh ini hanya memanfaatkan jasa berupa tenaga untuk melakukan proses kegiatan nelayan atau pesisir.

2) Skala investasi modal usaha

Pada kategori ini dibagi keadalam dua kelompok yaitu nelayan besar dan nelayan kecil. Nelayan besar bermakna memiliki modal yang cukup kuat yang dapat diinvestasikan/penanaman modal dalam kegiatan yang berhubungan dengan nelayan dibandingkan dengan nelayan kecil.

3) Teknologi yang digunakan dalam penangkapan

Pada kategori ini dibagikan dalam dua kelompok yaitu nelayan modern dan nelayan tradisional. Nelayan modern dapat diamati pada peralatan yang digunakan dalam proses pemanfaatan sumber daya laut, peralatan yang digunakan tergolong canggih dibandingkan dengan nelayan tradisional yang menggunakan peralatan yang bersifat tradisional dalam pemanfaatan sumberdaya laut.

\section{Sosial Ekonomi}

Susanto (1983:9) menjelaskan bahwa konsep sosial ditinjau sebagai sebuah aktivitas atau kegiatan yang berkaitan dengan masyarakat secara luas. Kata social berasal dari kata sozius yang bermakna "teman". Oleh karena itu manusia sebagai makhluk sosial melahirkan interaksi sosial yang dilakukan oleh sekumpulan orang, 
Community: Volume 7, Nomor 1, April 2021

p-ISSN: 2477-5746 e-ISSN: 2502-0544

saling tergantung dan tidak dapat melepaskan diri dari hubungan dengan individuindividu lainnya, sehingga kemudian manusia disebut sebagai makhluk sosial.

Damsar dan Indrayani (2016:9) menjelaskan bahwa kata ekonomi merupakan bentuk kata serapan dari bahasa Inggris yaitu economy, dimana istilah economy itu sendiri berasal dari bahasa Yunani yaitu oikonomike yang bermakna pengelolaan rumah tangga. Makna ekonomi sebagai pengelolaan rumah tangga merupakan suatu bentuk pengambilan keputusan dalam pengalokasian sumber daya rumah tangga yang terbatas. Oleh karena itu, rumah tangga selalu dihadapkan pada pengambilan keputusan atau pembuatan keputusan. Rumah tangga harus mampu menentukan anggota kelompok, pekerjaan, dan juga imbalan.

Astrawan (2014) menjelaskan konsep sosial ekonomi merupakan sebagai sebuah posisi atau kedudukan individu dalam suatu kelompok masyarakat yang ditentukan oleh aspek aktivitas ekonomi, pendidikan maupun pendapatan. Sejalan dengan Santrock (2007:282) status sosial ekonomi sebagai sebuah pengelompokan berbagai individu yang memiliki berbagai kesamaan, baik kesamaan dari karakteristik pekerjaan maupun kesamaan dari sisi pendidikan dan juga ekonomi (Pangi, 2020).

Sosial yang bermakna masyarakat atau teman. Setiap individu lahir dari berbagai keterbatasan-keterbatasan yang alamiah, kemudian memulai hidup saling berinteraksi dengan individu-individu lainnya dalam berbagai kegiatan untuk melangsungkan kehidupan. Berteman atau berkawan sekaligus saling membina kesetiakawanan merupakan ciri khas yang menonjol dari kehidupan sosial. Oleh karena itu manusia sebagai makhluk sosial tidak dapat hidup sendiri, manusia akan terus hidup secara bersama dan berdampingan sebagai makhluk sosial.

Anonimous (2007) menjelaskan istilah ekonomi sebagai ilmu yang berhubungan dengan asas produksi, distribusi, pemakaian barang, serta kekayaan. Dalam sosiologi kehidupan masyarakat sangat mempengaruhi pertumbuhan ekonomi, begitu sebaliknya dimana keduanya saling mempengaruhi. Jadi kesimpulannya adalah bahwa sosial ekonomi menggambarkan kehidupan masyarakat dalam hal pemenuhan kebutuhan baik sandang, pangan, maupun papan.

\section{Perubahan sosial}

Pada kajian ini penulis membaca bahwa terjadi perubahan sosial dan ekonomi pada masyarakat kampung Teluk Ambun. Masyarakat yang sebelumnya bermata pencaharian dengan menggantungkan hidupnya pada sumberdaya alam yaitu sungai (nelayan), kemudian harus bergeser pada pola mata pencaharian yang berbeda, yaitu bergeser pada perkebunan atau pertanian. Perubahan pola mata pencaharian ini kemudian dihadapkan pada persoalan baru yaitu harus dapat menyesuaikan diri dengan pola-pola kehidupan baru yang sebelumnya mereka tidak memiliki pengalaman.

Perubahan sosial sendiri seperti yang dijelaskan oleh Max Weber dapat bermakna perubahan situasi tertentu karena ketidaksesuaian unsur-unsur (Baharuddin, 
2015). Dalam hal ini perubahan yang terjadi di kampung Teluk Ambun, karena terjadinya perubahan situasi alam yang mengharuskan masyarakat bergeser pada polapola kehidupan baru yang sebelumnya mereka belum memiliki pengalaman. Perubahan sosial dan ekonomi masyarakat akan terus berubah sesuai dengan situasi tertentu, masyarakat suka atau tidak suka akan bergeser dari satu titik ke titik tertentu, karena situasi tertentu.

Dalam kehidupan masyarakat, tentu saja subjek-subjek memiliki berbagai kebutuhan hidup dan juga keinginan-keinginan yang tidak terbatas yang kemudian mendorong terjadinya perubahan sosial dan ekonomi. Perubahan-perubahan dapat mencakup: perlengkapan dan peralatan hidup, pola mata pencaharian, sistem kemasyarakatan, kesenian, sistem pengatahuan, termasuk persoalan keyakinan (Baharuddin, 2015). Pada kajian ini jelas bahwa masyarakat Teluk Ambun dihadapkan pada masyarakat yang sebelumnya berpola mata pencaharian sebagai nelayan kemudian bergeser pada masyarakat petani atau pekebun, karena situasi alam yang berubah.

\section{METODE PENELITIAN}

Penelitian ini menggunakan penelitian kualitatif yaitu penelitian yang bermaksud untuk memahami fenomena tentang apa yang dialami oleh subyek penelitian dengan cara deskripsi dalam bentuk kata-kata dan bahasa, pada suatu konteks khusus yang alamiah dan dengan memanfaatkan berbagai metode ilmiah.

Penelitian ini ingin menjelaskan bagaimana perubahan sosial ekonomi masyarakat nelayan pasca transmigrasi daerah di Kampung Teluk Ambun Kecamatan Singkil Utara Kabupaten Aceh Singkil. Adapun yang menjadi informan dalam penelitian ini adalah 2 orang toke ikan dan 8 orang nelayan. Adapun yang menjdi sumber data di dalam penelitian ini adalah pertama sumber data primer yaitu data yang diperoleh langsung dari objek yang akan diteliti (responden). Data ini diperoleh dari hasil wawancara dengan toke ikan dan nelayan. Kedua, sumber data sekunder yang diperoleh dari dokumen, rekaman dan sebagainya. Sedangkan untuk teknik pengumpulan data dalam penelitian ini adalah adanya observasi, wawancara, dan dokumentasi.

\section{TEMUAN DAN PEMBAHASAN}

Hasil temuan lapangan menunjukkan terjadi perubahan sosial ekonomi masyarakat nelayan khususnya pada aspek pendapatan. Pasca transmigrasi daerah, pendapatan masyarakat nelayan cenderung meningkat. Hal ini disebabkan karena anggota keluarga ikut andil dalam memenuhi kebutuhan rumah tangga, sebelumnya sumber pendapatan masyarakat nelayan hanya bergantung kepada kepala keluarga yaitu nelayan itu sendiri. Namun dengan adanya transmigrasi daerah, sumber pendapatan bisa didapatkan seorang istri, sebelumnya istri seorang nelayan hanya berprofesi sebagai ibu rumah tangga yang tidak berpenghasilan, kini berbagai macam pekerjaan bisa 
didapatkan, mulai dari sebagai asisten rumah tangga, baby sister, hingga menekuni profesi sebagai pedagang. Daerah yang saat ini memiliki jarak yang dekat dengan Ibu Kota Aceh Singkil yaitu Singkil, sangat membantu/mendorong perekonomian masyarakat nelayan.

Selain perubahan di atas, terdapat juga perubahan pada aspek pendapatan dari aspek pekerjaan. Dipengaruhi dari hasil tangkapan ikan atau lokan (kerang) yang tidak tetap tergantung cuaca dan kondisi, kini masyarakat nelayan mulai menekuni profesi sebagai petani sawit. Hasil sebagai petani sawit lebih menjanjikan, apalagi saat ini harga sawit sangat fantastis (mahal) yang memberikan keuntungan bagi masyarakat nelayan. Pekerjaan sebagai petani sawit merupakan peralihan pekerjaan utama yang dilakukann masyarakat nelayan. Dilihat dari profesi sebagai nelayan terus berkurang, sementara profesi sebagai petani sawit terus bertambah. Sebagaimana hasil wawancara salah satu nelayan di Kampung Teluk Ambun yang menjelaskan bahwa "saat ini masyarakat mulai sibuk dengan kebun sawitnya".

Fenomena ini menunjukkan bahwa masyarakat nelayan Teluk Ambun yang aktivitas pekerjaannya berkaitan dengan sumber daya (perairan/sungai), mengalami penurunan pendapatan akibat ketidaktersediaan sumber daya. Sebelumnya jarak tempun terhadap sumber daya dengan pemukiman sangat dekat, sehingga mempermudah mereka melakukan aktivitas nelayan. Akan tetapi pasca transmigrasi daerah membuat kegiatan pekerjaan sebagai nelayan jadi sulit, sehingga menuntut masyarakat mengubah mata pencahariana untuk dapat bertahan hidup.

Tidak dapat dipungkiri segala perubahan yang ada juga membawa dampak negatif, beberapa nelayan mengalami penurunan pendapatan. Sebelumnya nelayan bisa intens bekerja mencari ikan ataupun kerang (lokan), kini terhambat karena memiliki jarak tempuh yang jauh dari rumah ke sungai. Sebelumnya nelayan bisa memantau hasil tangkapan mereka tanpa memerlukan alat transportasi dan sekali-kali pulang ke rumah, namun kini nelayan harus menggunakan alat transportasi agar bisa melakukan aktivitas ekonomi tersebut. Untuk mengatasi masalah ini, masyarakat nelayan melakukan pekerjaan bersifat ganda yaitu lebih dari satu pekerjaan. Di malam hari beberpa nelayan memilih melakukan aktivitas ekonomi sebagai nelayan, sedangkan di siang hari mereka melakukan kegiatan ekonomi sebagai tukang, buruh, berdagang dan lain sebagainya.

Hasil penelitian ini juga menunjukkan bahwa setelah terjadinya transmigrasi daerah, mengubah pola pikir nelayan terhadap pentingnya pendidikan. Hal ini terlihat dari masyarakat nelayan yang saat ini memberikan pendidikan yang baik bagi anaknya melalui institusi pendidikan (sekolah), bahkan saat ini tidak sedikit anak nelayan menyelesaikan sekolah dan beberapa diantaranya mampu melanjutkan pendidikan sampai ke perguruan tinggi. Sebagian besar masyarakat nelayan hanya menyelesaikan pendidikan tingkat SD (sekolah dasar), namun dengan keterbatasan tersebut, para nelayan memberikan/menaruh harapan kepada anak-anaknya agar dapat mengubah nasib mereka sebagai nelayan. 
Untuk mewujudkan harapan tersebut, para nelayan berusaha mencari penghasilan lebih agar bisa melanjutkan pendidikan anaknya sampai ke perguruan tinggi. Banyak masyarakat yang mencari pekerjaan sampingan, bahkan beberapa masyarakat mulai meninggalkan pekerjaan tersebut (sebagai nelayan) yang dipicu karena hasil dari nelayan tidak menjanjikan. Profesi sebagai nelayan merupakan pekerjaan yang berifat diwariskan. Oleh karenanya secara umum pekerjaan turun temurun yang satu ini tidak mengalami perubahan yang berarti, namun kini perubahan dapat terlihat dengan jelas.

Penelitian ini juga menunjukkan hasil adanya peruabahan motivasi yang signifikan, dilihat para nelayan kerap mengambil andil dan bepartisipasi dalam kegiatan yang meningkatkan pengetahuan. Terlepas dari keterbatasan pendidikan formal yang tidak selesai pada umumnya, mereka memanfaatkan kegitan-kegiatan pelatihan dan sosialisasi yang diadakan oleh pemerintah maupun organisasi. Mereka sangat antusias mengikutinya untuk meningkatkan keterampilan dan pengetahuan, bahkan masyarakat sendiri mengharapkan pemerintah atau pun organisasi untuk sering mengadakan sosialisasi. Hal ini menunjukkan bahwa saat ini masyarakat nelayan aktif berpartisipasi dalam kegiatan yang dilakukan oleh pemerintah daerah ataupun organisasi, dimana sebelumnya masyarakat nelayan sangat acuh dalam kegiatan seperti sosialisasi. Saat ini menurut nelayan dengan adanya keterampilan dan pengetahuan yang baik, mereka tidak perlu merasa khawatir apabila hasil tangkapan ikan atau lokan (kerang) berkurang yang berdampak langsung pada pemenuhan kebutuhan. Namun dengan adanya keterampilan dan pengetahuan yang dimiliki, secara langsung dapat dimanfaatkan untuk menutupi kekurangan kebutuhan tersebut.

\section{PENUTUP}

Berdasarkan hasil temuan dan pembahasan di atas, maka dapat disimpulkan sebagai berikut:

- Ada perubahan sosial ekonomi pada masyarakat nelayan, khususnya pada aspek pendapatan. Sebelumnya anggota rumah tangga hanya menggantungkan kebutuhan kepada kepala keluarga (nelayan), seorang nelayan hanya bekerja sendiri untuk menghidupi keluarga. Kini pasca terjadinya transmigrasi daerah sumber penghasilan bisa di dapatkan dari anggota keluarga lainnya, sehingga sumber pendapatan tidak bergantung hanya kepada satu anggota keluarga saja.

- Perubahan sosial ekonomi juga dapat dilihat dari aspek pekerjaan. Pasca terjadinya transmigrasi daerah, menuntut masyarakat untuk tidak bergantung pada pekerjaan yang ia tekuni yaitu nelayan. Sumber daya di wilayah yang ditempati saat ini berbeda dengan sumber daya di wilayah sebelumnya. Akibatnya terdapat penurunan dari segi penghasilan, sehingga mendorong nelayan untuk memanfaatkan sumber daya yang ada, yaitu dengan berprofesi sebagai petani sawit. Namun, beberapa nelayan tetap mempertahankan 
profesinya sebagai nelayan, dimana ia tidak mampu beradaptasi dengan sumber daya yang ada saat ini. Akibatnya, penghasilan yang didapatkan menurun jika dibandingkan sebelum terjadinya transmigrasi daerah.

- Penelitian ini juga menunjukkan hasil bahwa, adanya perubahan pada aspek pola pikir terhadap pendidikan. Terlihat dari masyarakat nelayan yang saat ini memberikan pendidikan yang baik bagi anaknya, melalui institusi pendidikan (sekolah). Bahkan beberapa dari mereka mampu menyelesaikan studi hingga ke perguruan tinggi.

- Selain itu para nelayan yang terbatas akan pendidikan formal, berusaha mendapatkan dan meningkatkan pengetahuan dengan berpartisipasi pada kegiatan pelatihan dan sosialisasi.

\section{DAFTAR PUSTAKA}

Anonimous, 2007. Modul Terapan Pedoman Perencanaan Tata Ruang Kawasan Reklamasi Pantai. Jakarta: Departemen Pekerjaan Umum.

Baharuddin, 2015. Bentuk-Bentuk Perubahan Sosial dan Kebudayaan, JurnaL AlHikmah. pp. 180-205.

Damsar dan Indrayani. 2016. Pengantar Sosiologi Ekonomi. PT Kharisma Putra Utama: Kencana.

Imron. 2003. Pengembangan Ekonomi Nelayan dan Sistem Sosial Budaya. Jakarta: PT. Gramedia.

Koentjaraningrat. 1996. Pengantar Antropologi. Jakarta: Rineka Cipta

Kusnadi. 2006. Konflik Sosial Nelayan Kemiskinan Dan Perebutan Sumber Daya Perikanan. Yogyakarta: PT. LKiS Pelangi Aksara

Pangi, Joris. dkk. 2020. Kehidupan sosial ekonomi petani di Desa Maliku Satu Kecamatan Amurang Timur Kabupaten Minahasa Selatan. Jurnal Holistik. Vol.13, No. 1.

S. Susanto, Astrid. 1983. Pengantar Sosiologi dan Perubahan Sosial. Binacipta.

Sastrawidjaya. 2002. Nelayan dan Kemiskinan. Jakarta: Pradnya Paramita.

Satria, Arif. 2015. Pengantar Soiologi Masyrakat Pesisir. Jakarta: Yayasan Pustaka Obor Indonesia. 